\title{
Preliminary Assessment of the Energy-Saving Potential of Electrochromic Windows in Residential Buildings
}

Technical Report NREL/TP-550-46916

December 2009

David R. Roberts 


\section{Preliminary Assessment of the Energy-Saving Potential of Electrochromic Windows in Residential Buildings}

Technical Report NREL/TP-550-46916

December 2009

David R. Roberts

Prepared under Task No. BET98001

National Renewable Energy Laboratory 1617 Cole Boulevard, Golden, Colorado 80401-3393 303-275-3000 • www.nrel.gov

NREL is a national laboratory of the U.S. Department of Energy

Office of Energy Efficiency and Renewable Energy

Operated by the Alliance for Sustainable Energy, LLC

Contract No. DE-AC36-08-GO28308

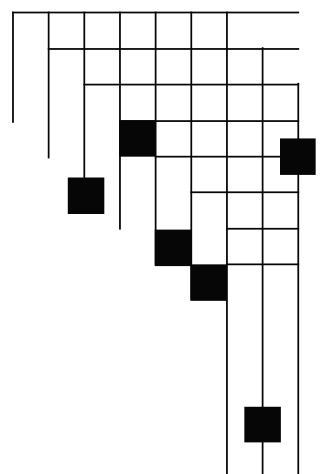




\section{NOTICE}

This report was prepared as an account of work sponsored by an agency of the United States government. Neither the United States government nor any agency thereof, nor any of their employees, makes any warranty, express or implied, or assumes any legal liability or responsibility for the accuracy, completeness, or usefulness of any information, apparatus, product, or process disclosed, or represents that its use would not infringe privately owned rights. Reference herein to any specific commercial product, process, or service by trade name, trademark, manufacturer, or otherwise does not necessarily constitute or imply its endorsement, recommendation, or favoring by the United States government or any agency thereof. The views and opinions of authors expressed herein do not necessarily state or reflect those of the United States government or any agency thereof.

Available electronically at http://www.osti.gov/bridge

Available for a processing fee to U.S. Department of Energy and its contractors, in paper, from:

U.S. Department of Energy

Office of Scientific and Technical Information

P.O. Box 62

Oak Ridge, TN 37831-0062

phone: 865.576 .8401

fax: 865.576 .5728

email: mailto:reports@adonis.osti.gov

Available for sale to the public, in paper, from:

U.S. Department of Commerce

National Technical Information Service

5285 Port Royal Road

Springfield, VA 22161

phone: 800.553.6847

fax: 703.605.6900

email: orders@ntis.fedworld.gov

online ordering: http://www.ntis.gov/ordering.htm 


\section{Executive Summary}

Electrochromic (EC) windows provide variable tinting that can help control glare and solar heat gain. We used BEopt software to evaluate the performance of EC windows in prototypical energy models of a single-family home in Atlanta. The windows were assumed to operate automatically, tinting in response to incident solar during the cooling season. The models predict the EC windows will produce whole-house source energy savings of $9.1 \%$ and whole-house electricity demand savings of $13.5 \%$ in a 2006 IECCcompliant home, and source energy savings of $3.2 \%$ and demand savings of $10.3 \%$ in a 50\%-level Building America home. 


\section{Contents}

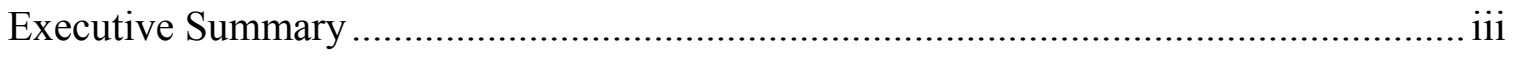

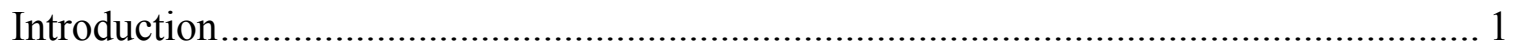

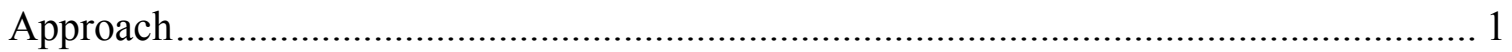

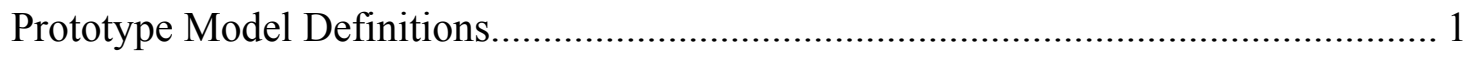

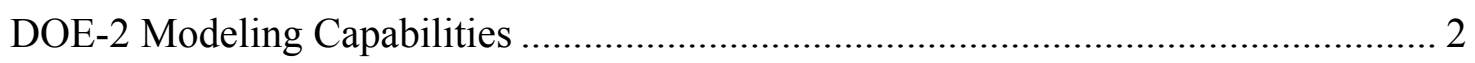

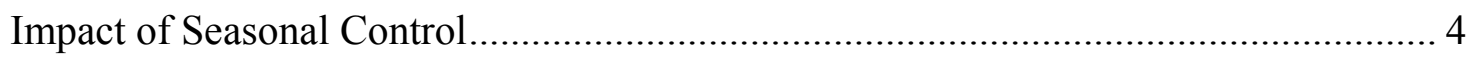

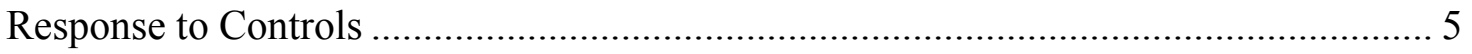

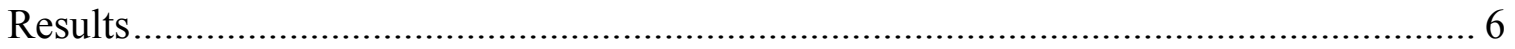

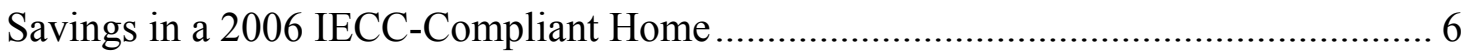

Savings in a 50\% Building America Home .......................................................... 8

Cost-Competitive EC Windows............................................................................. 10

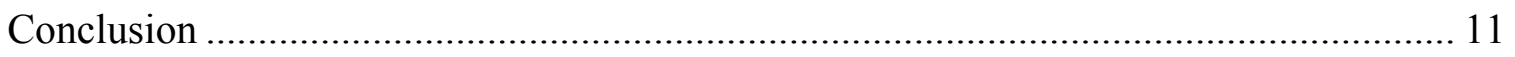

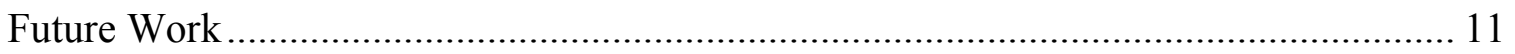

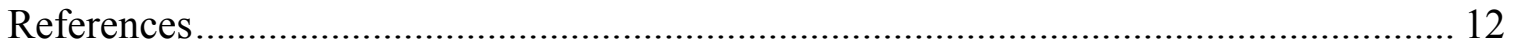




\section{Figures}

Figure 1. EC window tinting response to total solar incident on window ....................... 3

Figure 2. Heating and cooling source energy use in Atlanta reference home................... 4

Figure 3. EC window tinting for each hour of the year-west-facing window ............... 5

Figure 4. EC window tinting for each hour of the day .................................................... 6

Figure 5. Fully tinted equivalent hours for each hour, by orientation............................... 6

Figure 6. BEopt output for source energy savings for EC windows relative to low-e,

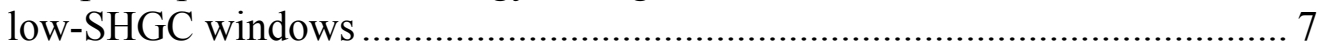

Figure 7. Electricity demand for cooling with EC windows and code-compliant reference windows in 2006 IECC home on July 2 and 3 .............................. 8

Figure 8. BEopt output for source energy savings from EC windows in 50\% Building America home....

Figure 9. Electricity demand for cooling (compressor and fan) with EC windows and reference windows in 2006 IECC home on July 2 and 3............................ 10

Figure 10. BEopt output. EC glazing is competitive at approximately $\$ 20 / \mathrm{ft}^{2} \ldots \ldots \ldots \ldots \ldots . . .11$

\section{Tables}

Table 1. General Characteristics of the Prototype Energy Models ................................. 1

Table 2. Prototype Model Performance Levels ............................................................... 2

Table 3. Characteristics of SageGlass EC Glazing and DOE-2.2 Window Library

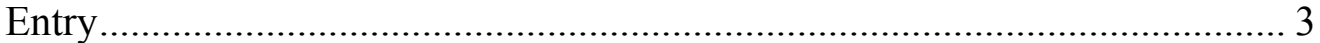

Table 4. Source Energy Impacts of Disabling EC Control During Heating Season

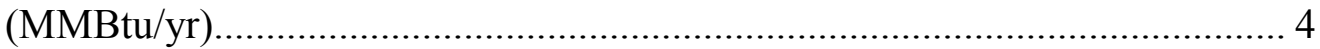

Table 5. Energy Cost Impacts of Disabling EC Control During Heating Season ( $\$$ /yr)........ 5

Table 6. Source Energy Savings From EC Windows in 2006 IECC home (MMBtu/yr) ... 7

Table 7. Energy Cost Savings From EC Windows in 2006 IECC Home (\$/yr)............. 7

Table 8. July 3 Peak Electricity Demand Savings From EC Windows in 2006 IECC-

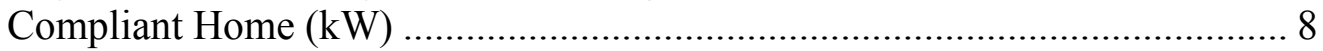

Table 9. Source Energy Savings From EC Windows in 50\% Building America Home (MMBtu/yr).

Table 10. Energy Cost Savings From EC Windows in 50\% Building America Home $(\$ / y r)$

Table 11. July 3 Peak Electricity Demand Savings From EC Windows in 50\% Building America Home (kW). 


\section{Introduction}

Electrochromic (EC) windows provide variable tinting that can help control glare and solar heat gain. The windows darken in response to changes in applied electrical voltage ${ }^{1}$ and can be controlled manually or automatically. EC windows are available commercially, though currently their use is generally limited to commercial building applications and residential skylights. A study by Lee et al. (2006) that focused on commercial building applications reported significant energy and demand savings, based on empirical testing and energy modeling.

This report summarizes the results of a simple energy modeling exercise conducted to assess the impact EC windows might have in residential applications.

\section{Approach}

\section{Prototype Model Definitions}

We used energy modeling to assess the potential impact of installing EC windows in a single-family home and used the BEopt ${ }^{2}$ software to develop and analyze prototype single-family home models. General characteristics of the prototype models are shown in Table 1.

Table 1. General Characteristics of the Prototype Energy Models

\begin{tabular}{|l|l|}
\hline Conditioned floor area & $2,500 \mathrm{ft}^{2}$ \\
\hline Conditioned volume & $22,500 \mathrm{ft}^{3}$ \\
\hline Number of stories & 2 \\
\hline Number of bedrooms & 3 \\
\hline Gross above-grade wall area & $2,574 \mathrm{ft}^{2}$ \\
\hline Window area & $450 \mathrm{ft}^{2}(18 \%$ of conditioned floor area) \\
\hline Window orientation & $50 \%$ west, $25 \%$ east, $12.5 \%$ north, 12.5\% south \\
\hline Window interior shading factors & 0.85 winter, 0.7 summer \\
\hline Door area & $40 \mathrm{ft}^{2}$ \\
\hline Set point temperatures & 71 heating, 76 cooling \\
\hline Mechanical ventilation & Exhaust only, ASHRAE 62.2 levels \\
\hline Space/water heating fuel & Natural gas \\
\hline Internal gains & Building America Benchmark (Hendron 2008) \\
\hline Lighting/appliance/plug schedules & Building America Benchmark \\
\hline
\end{tabular}

* This is the standard assumption in Building America, HERS, and IECC analysis.

\footnotetext{
${ }^{1}$ Nominally averages $0.5 \mathrm{~W} / \mathrm{m}^{2}$ of glazing (Sbar 2009).

${ }^{2}$ The BEopt software tool was developed at NREL to identify optimal building energy designs aimed at minimizing the total of the amortized cost of improvements and the cost of energy. It produces designs that minimize combined construction and energy costs by using the DOE-2.2 and TRNSYS energy simulation programs to automate a sequential search technique for locating least-cost solutions on a path toward net zero energy. The software and underlying methodology are described in detail by Christensen et al. (2005, 2006) and Horowitz et al. (2008).
} 
Atlanta was selected as an appropriate climate for assessing the energy-savings potential of EC windows, as it produces fairly balanced and substantial heating and cooling loads in residential buildings. Solar gain is beneficial at times because it reduces heating loads in the winter and undesirable at times as it contributes to cooling loads in the summer.

Two prototypical models were developed with the general characteristics outlined in Table 1, but differing performance characteristics. The first meets the requirements of the 2006 International Energy Conservation Code (IECC) for Atlanta, climate zone 3. The second includes performance characteristics of an Atlanta home using 50\% less source energy than the Building America Benchmark, as described by Anderson and Roberts (2008). The performance characteristics of both are shown in Table 2.

Table 2. Prototype Model Performance Levels

\begin{tabular}{|l|l|l|}
\hline \multicolumn{1}{|c|}{ Component } & \multicolumn{1}{|c|}{ 2006 IECC } & \multicolumn{1}{c|}{$\mathbf{5 0 \%}$ Building America } \\
\hline Walls & $2 \times 4$, R-13 cavity & $2 \times 6$, R-21 cavity \\
\hline Ceiling & R-30 & R-40 \\
\hline Infiltration & 0.00050 SLA & 0.00015 SLA \\
\hline Window U-value & 0.65 & 0.30 \\
\hline Window SHGC & 0.40 & 0.26 \\
\hline Lighting & $14 \%$ fluorescent & $90 \%$ fluorescent \\
\hline Air conditioner & SEER 13 & SEER 15 \\
\hline Furnace & 80 AFUE & 92 AFUE \\
\hline Ducts & R-8, in crawl space & In conditioned space \\
\hline Water heater & 0.59 EF & 0.77 EF \\
\hline Appliances & ENERGY STAR \\
\hline AFUE $=$ Annual Fuel Utilization Efficiency \\
EF $=$ Energy Factor \\
SEER $=$ Seasonal Energy Efficiency Ratio \\
SHGC $=$ Solar Heat Gain Coefficient \\
SLA $=$ Specific Leakage Area &
\end{tabular}

\section{DOE-2 Modeling Capabilities}

The BEopt software was modified to accommodate and model EC windows in the DOE2.2 simulation engine. DOE-2.2 provides a broad range of EC windows and controls. An EC window that best matches those currently available ${ }^{3}$ was selected from the DOE-2.2 window library (see Table 3 ).

\footnotetext{
${ }^{3}$ Sage Electrochromics, Inc. is currently the only producer of commercially available EC glazing.
} 
Table 3. Characteristics of SageGlass EC Glazing and DOE-2.2 Window Library Entry

\begin{tabular}{|l|c|c|c|c|}
\hline \multirow{2}{*}{} & \multicolumn{2}{|c|}{ U-Value } & \multicolumn{2}{c|}{ SHGC $^{*}$} \\
\cline { 2 - 5 } & Sage* $^{*}$ & DOE-2** $^{\text {* }}$ & Sage* $^{*}$ & DOE-2** $^{*}$ \\
\hline Clear state & 0.29 & 0.29 & 0.48 & 0.51 \\
\hline Tinted state & 0.29 & 0.29 & 0.09 & 0.13 \\
\hline
\end{tabular}

* SageGlass Classic ${ }^{\mathrm{TM}}$ (source: Sage Electrochromics Web site: www.sage-ec.com/pages/technol.html)

** DOE-2 2 library entries 2842/2843.

EC window controls available in DOE-2.2 include:

- Direct or total solar incident on the window

- Direct or total solar transmitted through the glazing

- Total horizontal solar

- Outside temperature

- Space load

- Interior daylight level.

These controls can also be combined with a seasonal/hourly time schedule.

We selected total solar incident on the window for control, as it allows the windows on each orientation to respond independently and is straightforward to implement in the field.

DOE-2.2 provides for low and high limits for the control variable. We assumed that tinting begins when solar incident on the window exceeds $100 \mathrm{Btu} / \mathrm{h} \cdot \mathrm{ft}^{2}$; the window is fully tinted at $150 \mathrm{Btu} / \mathrm{h} \cdot \mathrm{ft}^{2}$. Figure 1 shows how the window tinting responds to incident solar in the DOE-2.2 model.

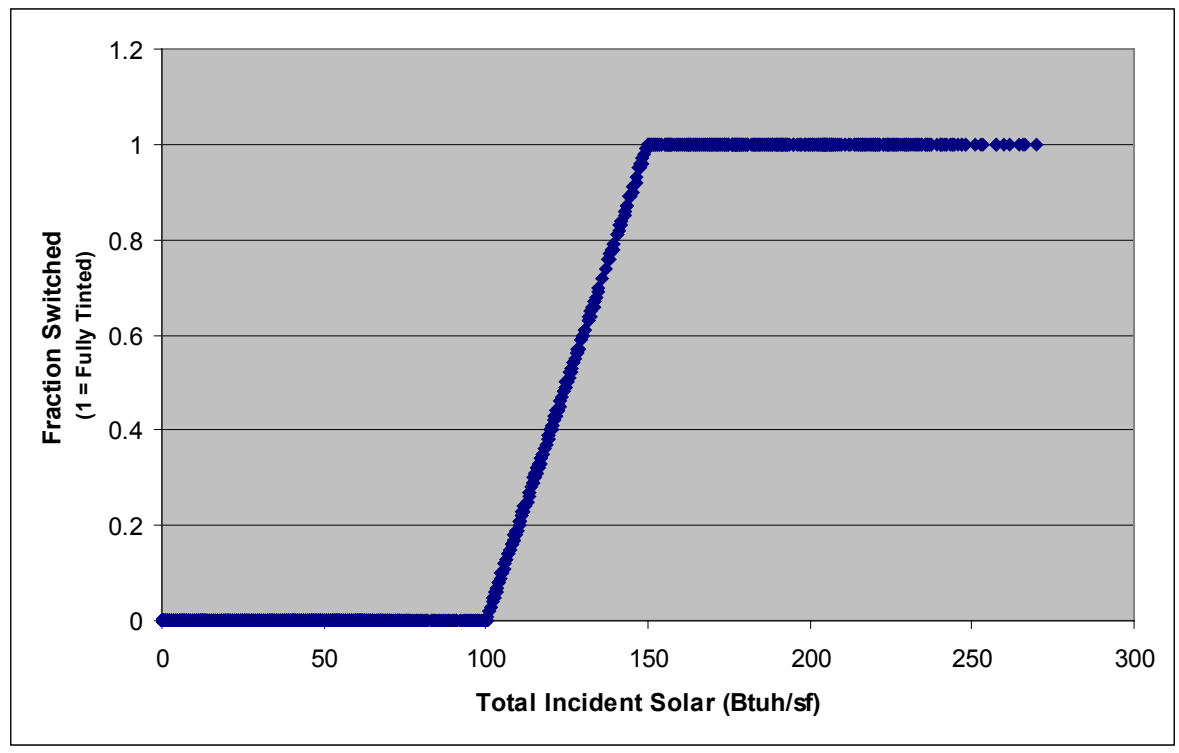

Figure 1. EC window tinting response to total solar incident on window 


\section{Impact of Seasonal Control}

As mentioned earlier, it is beneficial to maximize solar gain during the heating season. Figure 2 shows the monthly source energy use for space heating and cooling for the Atlanta prototype model with standard glazing. Ideally, the EC windows would not reduce solar gain during periods with large heating loads and small cooling loads. We "locked out" the EC window control during the heating season in the BEopt/DOE-2 model and examined the impact. Based on the heating and cooling loads in Figure 2, the EC control was fixed in the "Clear" mode from October 15 through April 15, and then switched into "Auto" mode during the balance of the year. In "Auto" mode the glazing responds to total solar incident on the window.

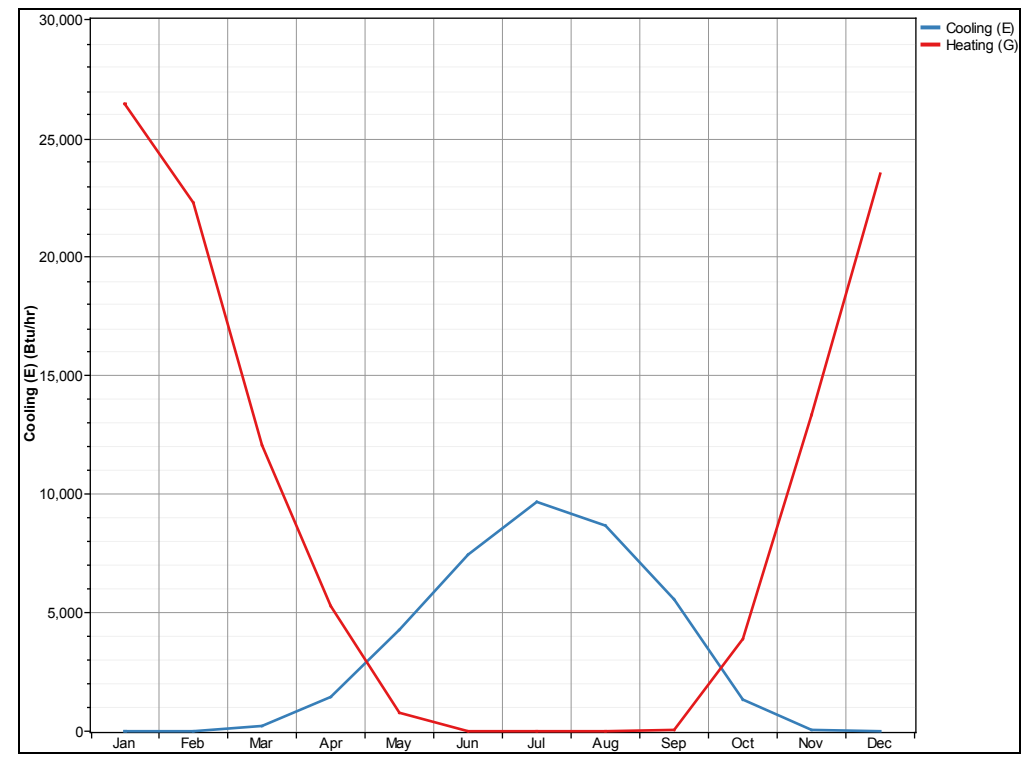

Figure 2. Heating and cooling source energy use in Atlanta reference home

The energy and cost impacts associated with locking out the EC windows during the heating season are shown in Table 4 and Table 5. It is clearly beneficial to lock out automated window tinting during the heating season. Based on these results, automated EC control is assumed to function from April 15 to October 15 only.

Table 4. Source Energy Impacts of Disabling EC Control During Heating Season (MMBtu/yr)

\begin{tabular}{|l|c|c|c|}
\hline & Heating $^{*}$ & Cooling* $^{*}$ & Total \\
\hline Automated year-round & 71.2 & 29.3 & 100.5 \\
\hline Automated April 15 to October 15 & 67.1 & 29.9 & 97.0 \\
\hline Absolute savings & 4.2 & -0.6 & 3.6 \\
\hline Percent savings & $5.9 \%$ & $-2.1 \%$ & $3.5 \%$ \\
\hline
\end{tabular}

* Includes fan energy 
Table 5. Energy Cost Impacts of Disabling EC Control During Heating Season (\$/yr)

\begin{tabular}{|l|c|c|c|}
\hline & Heating* $^{*}$ & Cooling* $^{*}$ & Total \\
\hline Automated year-round & 1105 & 202 & 1307 \\
\hline Automated April 15 to October 15 & 1040 & 206 & 1246 \\
\hline Absolute savings & 65 & -4 & 60 \\
\hline Percent savings & $5.9 \%$ & $-2.1 \%$ & $4.6 \%$ \\
\hline
\end{tabular}

* Includes fan energy

\section{Response to Controls}

Figure 3 shows the level of window tinting on the west-facing windows during each hour of the year. The windows do not tint during the lock-out period between April 15 and October 15.

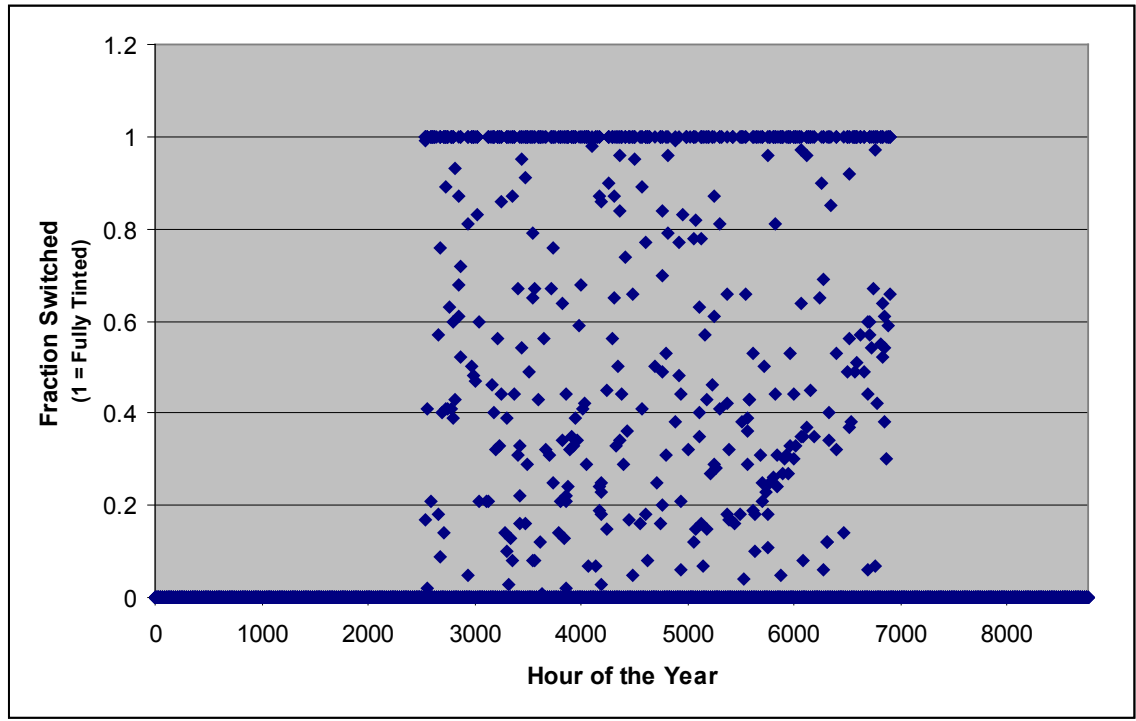

Figure 3. EC window tinting for each hour of the year-west-facing window

Figure 4 shows window tinting for all orientations by hour of the day. This graph demonstrates how the windows tint in response to the position of the sun throughout the day. 


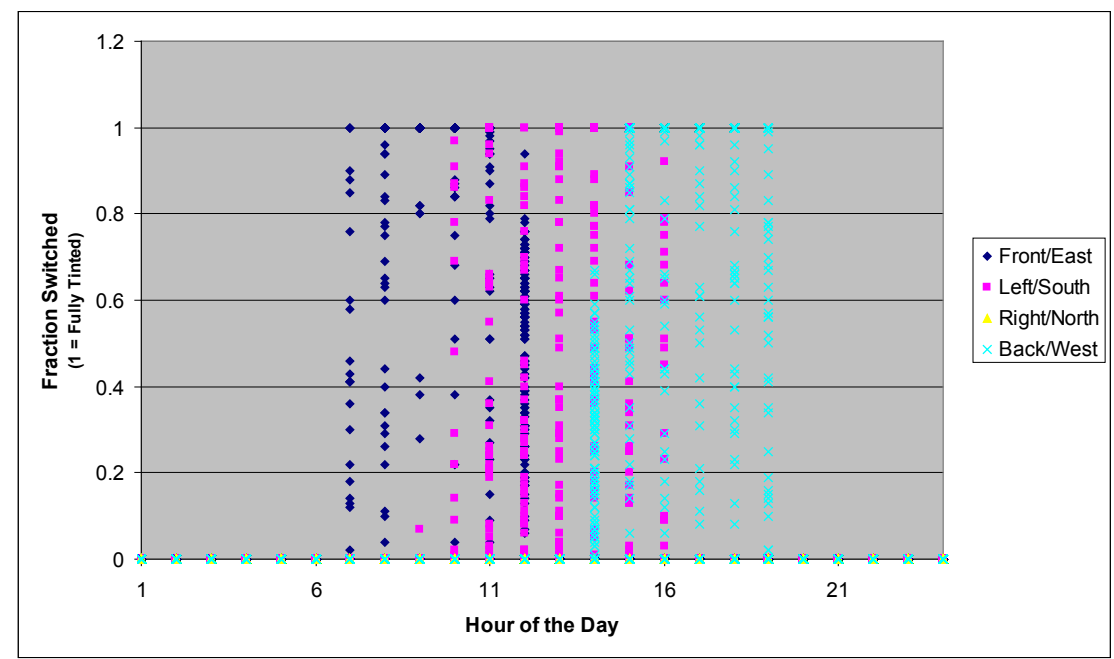

Figure 4. EC window tinting for each hour of the day

Figure 5 quantifies the level of tinting that occurs on each orientation using "fully tinted hours"- the sum of all tinting that occurs throughout the year. As one might expect, with winter hours locked out, most tinting occurs in east- and west-facing windows. The north-facing windows never tint.

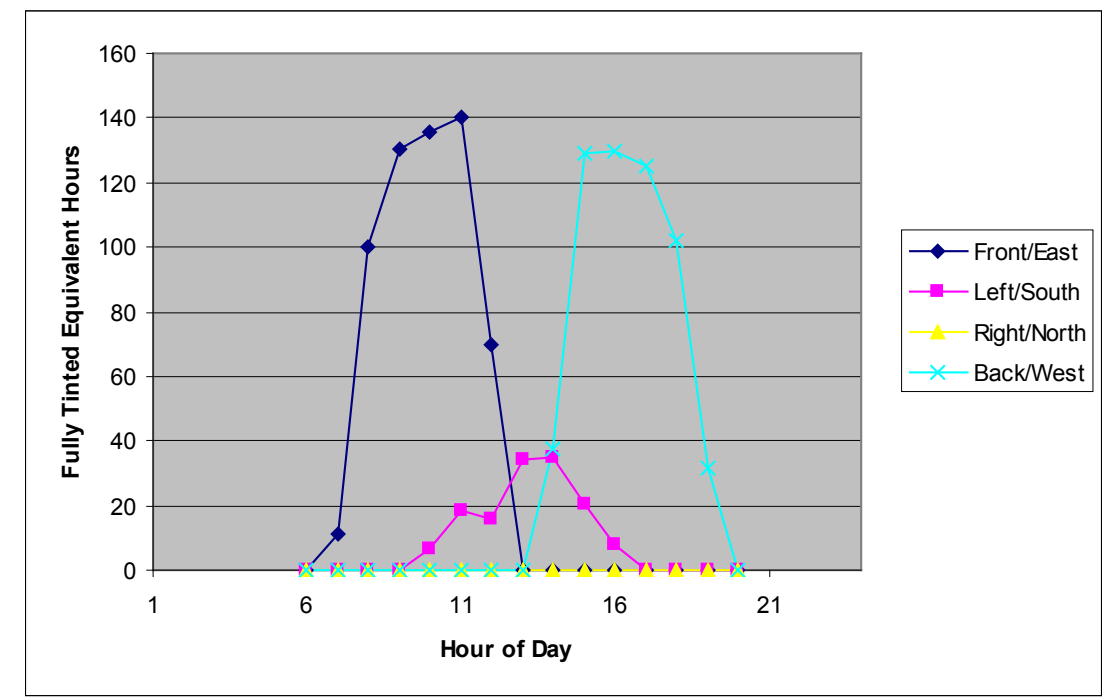

Figure 5. Fully tinted equivalent hours for each hour, by orientation

\section{Results}

\section{Savings in a 2006 IECC-Compliant Home}

Results of BEopt runs compare the source energy of the 2006 IECC prototype home with $\mathrm{EC}$ windows to the home with code-level windows (see Figure 6). The EC windows result in $9.1 \%$ savings in whole-house source energy. Table 6 shows $18.2 \%$ source energy savings for the heating and cooling end uses; Table 7 shows analogous cost savings of $19.5 \%$. 


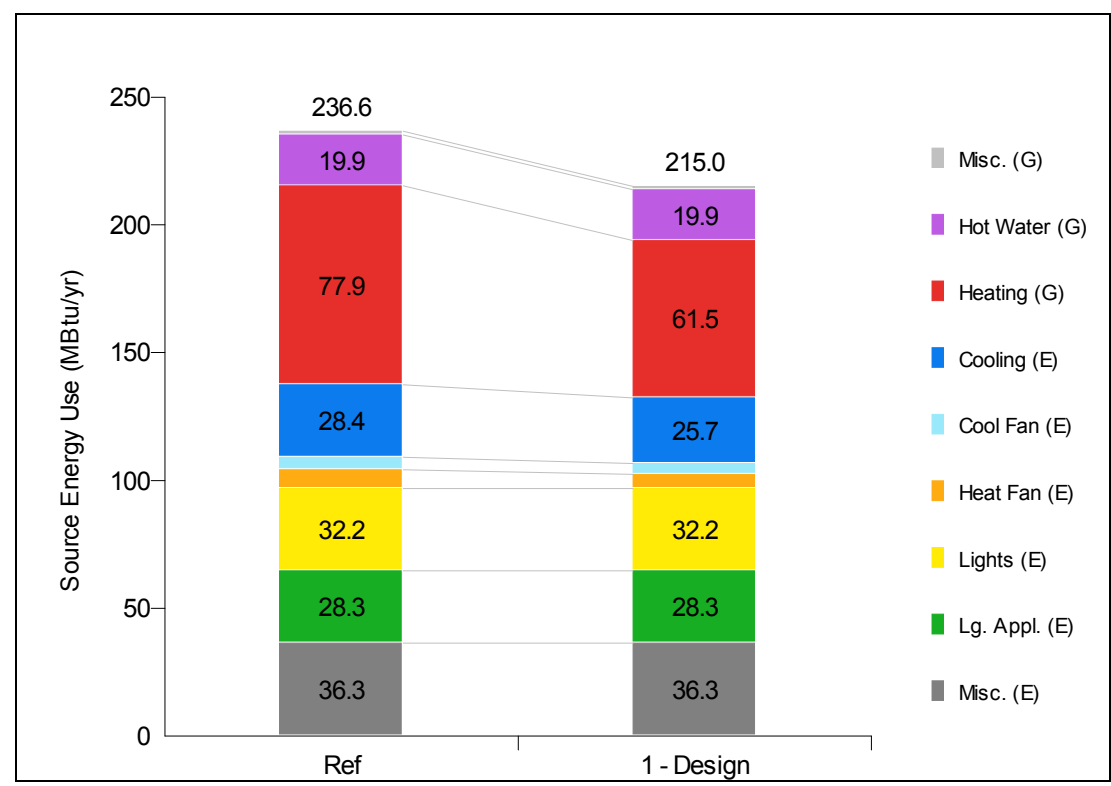

Figure 6. BEopt output for source energy savings for EC windows relative to low-e, lowSHGC windows

Table 6. Source Energy Savings From EC Windows in 2006 IECC home (MMBtu/yr)

\begin{tabular}{|l|c|c|c|}
\hline & Heating* $^{*}$ & Cooling $^{*}$ & Total \\
\hline 2006 IECC-compliant home & 85.2 & 33.3 & 118.5 \\
\hline 2006 IECC with EC windows & 67.1 & 29.9 & 97.0 \\
\hline Absolute savings & 18.1 & 3.4 & 21.5 \\
\hline Percent savings & $21.3 \%$ & $10.2 \%$ & $18.2 \%$ \\
\hline
\end{tabular}

* Includes fan energy

Table 7. Energy Cost Savings From EC Windows in 2006 IECC Home (\$/yr)

\begin{tabular}{|l|c|c|c|}
\hline & Heating* & Cooling* $^{*}$ & Total \\
\hline 2006 IECC-compliant home & 1319 & 230 & 1549 \\
\hline 2006 IECC with EC windows & 1040 & 206 & 1246 \\
\hline Absolute savings & 279 & 23 & 302 \\
\hline Percent savings & $21.1 \%$ & $10.2 \%$ & $19.5 \%$ \\
\hline
\end{tabular}

* Includes fan energy

The BEopt/DOE-2 model predicts a peak-day electricity demand reduction of $0.7 \mathrm{~kW}$, a $13.5 \%$ reduction in whole-house demand. Figure 7 shows the electricity demand for cooling for the two days with the highest predicted demand. Table 8 shows the demand savings at 7:00 p.m. on July 3, the peak hour for the year. 


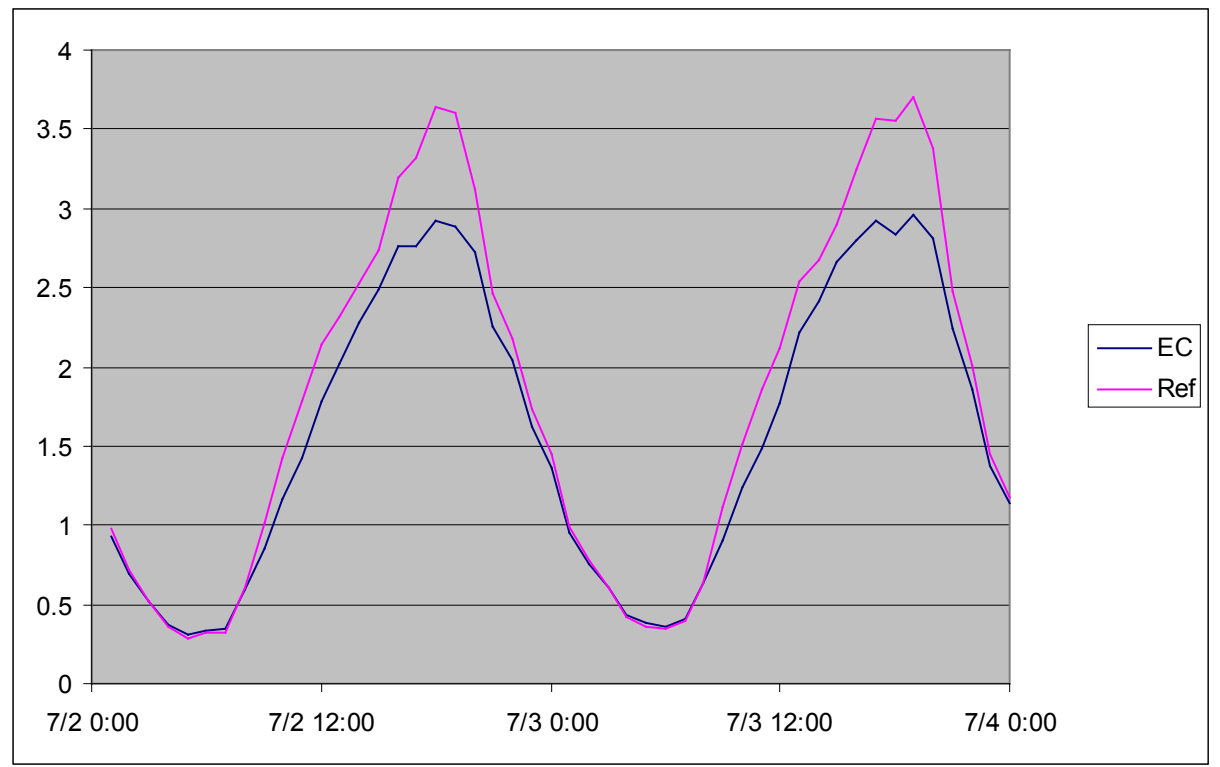

Figure 7. Electricity demand for cooling with EC windows and code-compliant reference windows in 2006 IECC home on July 2 and 3

Table 8. July 3 Peak Electricity Demand Savings From EC Windows in 2006 IECCCompliant Home (kW)

\begin{tabular}{|l|c|c|}
\hline & Cooling $^{*}$ & Whole-House $^{*}$ \\
\hline 2006 IECC-compliant home & 3.7 & 5.5 \\
\hline 2006 IECC with EC windows & 3.0 & 4.7 \\
\hline Absolute savings & 0.7 & 0.7 \\
\hline Percent savings & $19.9 \%$ & $13.5 \%$ \\
\hline
\end{tabular}

* Includes fan energy

\section{Savings in a $\mathbf{5 0 \%}$ Building America Home}

Results of BEopt runs comparing the source energy of the 50\% Building America prototype home with EC windows, to the home with low-e, low-SHGC, argon-filled windows, are shown in Figure 8. The EC windows result in 3.2\% savings in whole-house source energy. Table 9 shows $8.2 \%$ source energy savings for the heating and cooling end uses; Table 10 shows analogous cost savings of $9.4 \%$. 


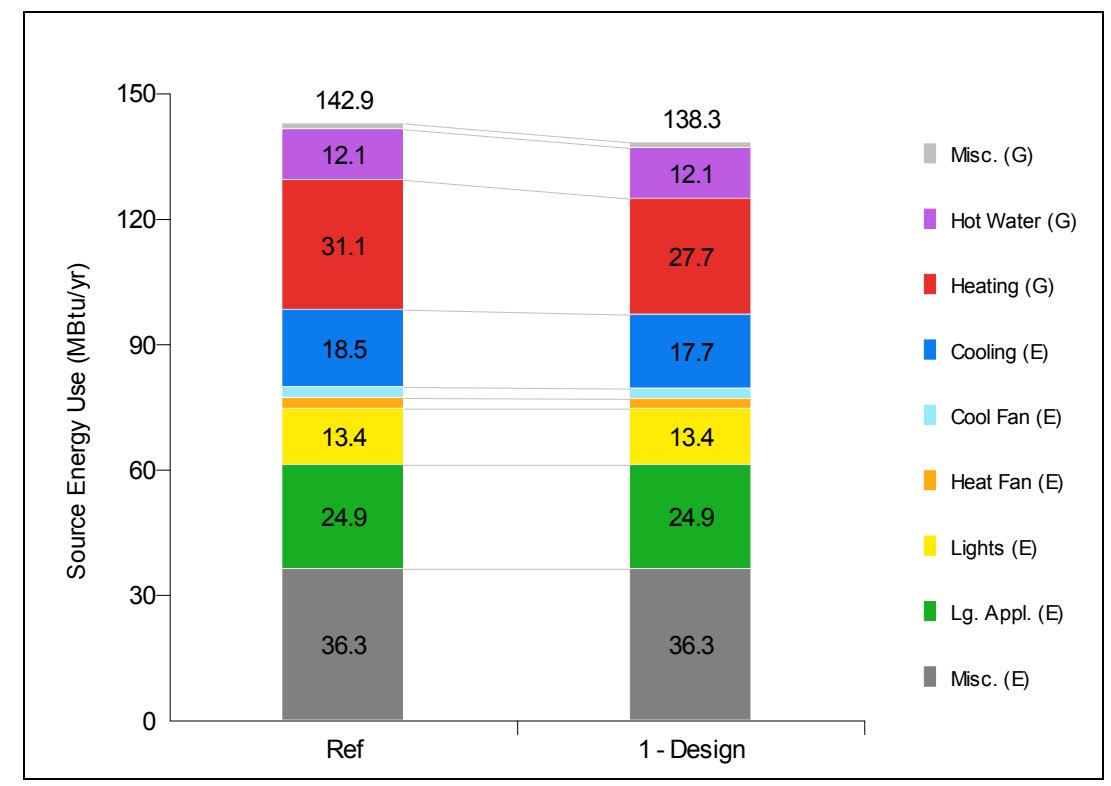

Figure 8. BEopt output for source energy savings from EC windows in $50 \%$ Building America home

Table 9. Source Energy Savings From EC Windows in 50\% Building America Home (MMBtu/yr)

\begin{tabular}{|l|c|c|c|}
\hline & Heating* $^{*}$ & Cooling $^{*}$ & Total \\
\hline $50 \%$ Building America home & 33.6 & 21.1 & 54.7 \\
\hline $50 \%$ Building America home with EC windows & 30.0 & 20.2 & 50.2 \\
\hline Absolute savings & 3.6 & 0.9 & 4.5 \\
\hline Percent savings & $10.7 \%$ & $4.2 \%$ & $8.2 \%$ \\
\hline
\end{tabular}

* Includes fan energy

Table 10. Energy Cost Savings From EC Windows in 50\% Building America Home (\$/yr)

\begin{tabular}{|l|c|c|c|}
\hline & Heating* $^{*}$ & Cooling $^{*}$ & Total \\
\hline $50 \%$ Building America home & 524 & 145 & 670 \\
\hline $50 \%$ Building America home with EC windows & 468 & 139 & 607 \\
\hline Absolute savings & 57 & 6 & 63 \\
\hline Percent savings & $10.8 \%$ & $4.2 \%$ & $9.4 \%$ \\
\hline
\end{tabular}

* Includes fan energy

The BEopt/DOE-2 model predicts a peak-day electricity demand reduction of $0.4 \mathrm{~kW}$, a $10.3 \%$ reduction in whole-house demand. Figure 9 shows the electricity demand for cooling for the two days with the highest predicted demand. Table 11 shows the demand savings at 7:00 p.m. on July 3, the peak hour for the year. 


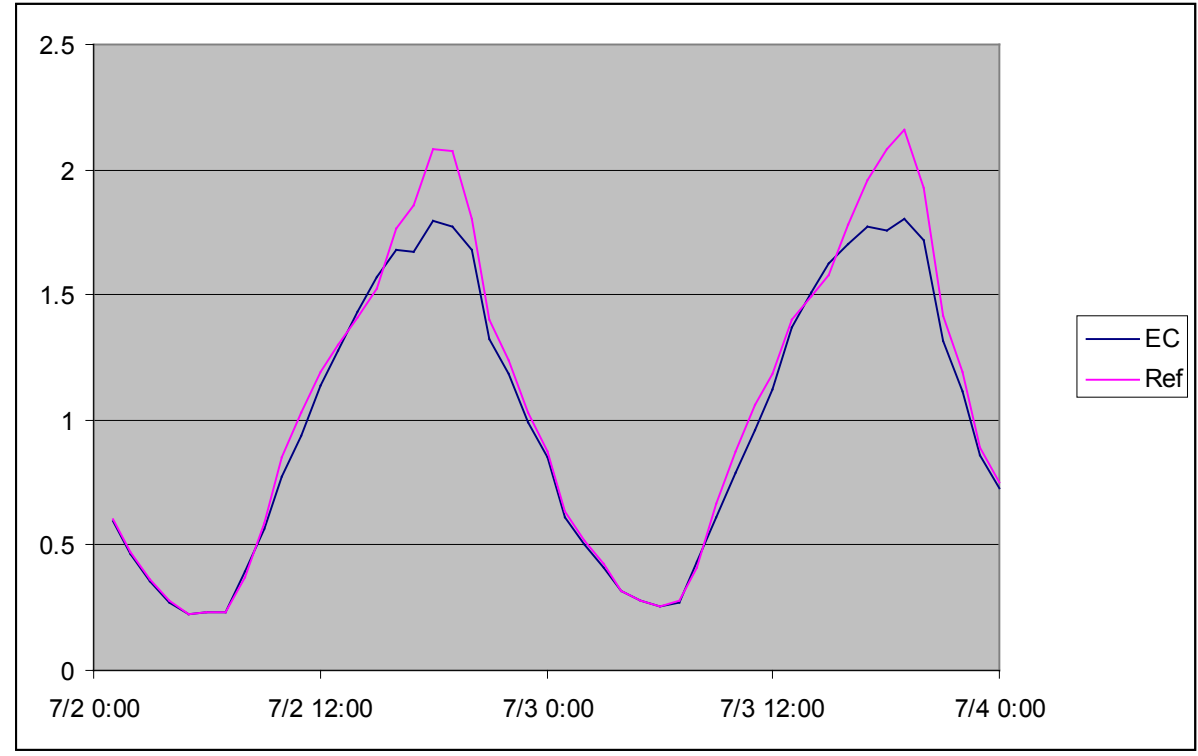

Figure 9. Electricity demand for cooling (compressor and fan) with EC windows and reference windows in 2006 IECC home on July 2 and 3

Table 11. July 3 Peak Electricity Demand Savings From EC Windows in $50 \%$ Building America Home (kW)

\begin{tabular}{|l|c|c|}
\hline & Cooling $^{*}$ & Whole House $^{-}$ \\
\hline $50 \%$ Building America home & 2.2 & 3.4 \\
\hline $50 \%$ Building America home with EC windows & 1.8 & 3.1 \\
\hline Absolute savings & 0.4 & 0.4 \\
\hline Percent savings & $16.4 \%$ & $10.3 \%$ \\
\hline
\end{tabular}

* Includes fan energy

\section{Cost-Competitive Electrochromic Windows}

We used the Atlanta 2006 IECC-compliant prototype model to run BEopt with a number of above-code features to identify the optimal non-EC windows for this home. BEopt identified low-e, low-SHGC, argon-filled windows as the most cost-effective upgrade at $\$ 16 / \mathrm{ft}^{2}$. This window was selected as an appropriate "competing technology" and the basis of this analysis. These same windows are in 50\% Building America home.

To determine the cost at which EC windows will be competitive, we ran BEopt with EC windows at different price points: from $\$ 40 / \mathrm{ft}^{2}$ down to $\$ 10 / \mathrm{ft}^{2}$. Figure 10 shows the BEopt curves for these windows along with the "competing technology": low-e, lowSHGC, argon-filled at $\$ 16 / \mathrm{ft}^{2}$. The graph indicates that EC windows would have to reach a price point of approximately $\$ 20 / \mathrm{ft}^{2}$ before they would be competitive with this window. EC windows currently cost $\$ 50-\$ 100 / \mathrm{ft}^{2}$; residential applications are on the higher end (Sbar). 


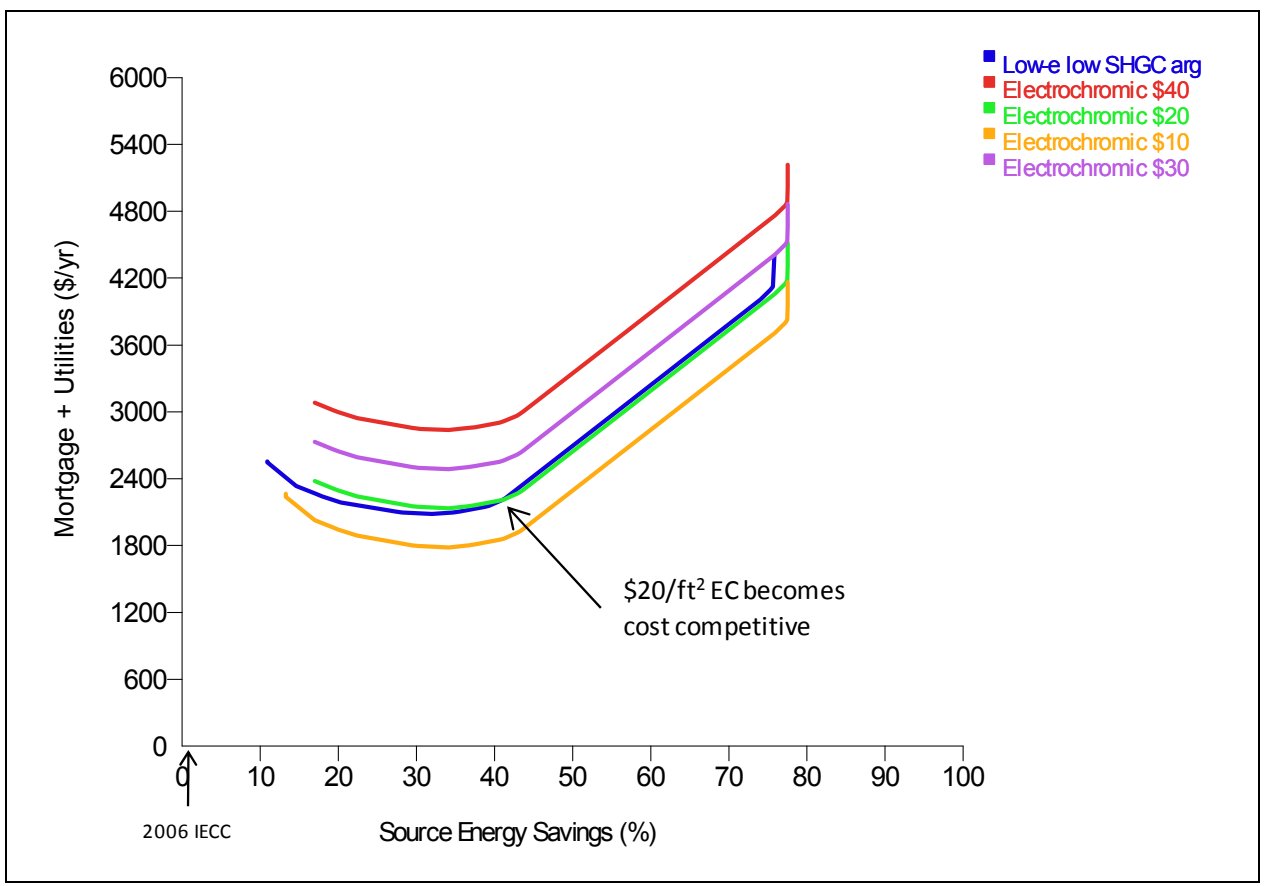

Figure 10. BEopt output. EC glazing is competitive at approximately $\$ 20 / \mathrm{ft}^{2}$.

\section{Conclusion}

A simple modeling study was undertaken to assess the potential energy savings of EC windows in residential applications. We used BEopt software to evaluate the performance of EC windows in prototypical energy models of a single-family home in Atlanta. The windows were assumed to operate automatically, tinting in response to incident solar during the cooling season. The model predicted the EC windows would produce wholehouse source energy savings of $9.1 \%$, and whole-house electricity demand savings of $13.5 \%$ in a 2006 IECC-compliant home and source energy savings of $3.2 \%$ and demand savings of $10.3 \%$ in a $50 \%$-level Building America home. Comparing the cost and modeled performance of EC windows to "competing technology" indicates EC windows would be competitive at a price point of approximately $\$ 20 / \mathrm{ft}^{2}$.

\section{Future Work}

Suggested future work to further assess the potential impact of EC windows in residential applications includes:

- Additional modeling

- Additional climates

- Compare performance to orientation-tuned glazing

- Examine other control strategies

O Optimize controls

- Monitoring installed performance

○ Test facility

- Unoccupied lab homes

- Occupied homes. 


\section{References}

Anderson, R.; Roberts, D. (2008). Maximizing Residential Energy Savings: Net Zero Energy Home (ZEH) Technology Pathways. Golden, CO: National Renewable Energy Laboratory, NREL/TP-550-44547.

Christensen, C.; Horowitz, S.; Givler, T.; Courtney, A.; Barker, G. (2005). BEopt: Software for Identifying Optimal Building Designs on the Path to Zero Net Energy. Golden, CO: National Renewable Energy Laboratory, NREL/CP-550-37733.

Christensen, C.; Anderson, R.; Horowitz, S.; Courtney, A.; Spencer, J. (2006). BEopt(TM) Software for Building Energy Optimization: Features and Capabilities. Golden, CO: National Renewable Energy Laboratory, NREL/TP-550-39929.

Horowitz, S.; Christensen, C.; Brandemuehl, M.; Krarti, M. (2008). Enhanced Sequential Search Methodology for Identifying Cost-Optimal Building Pathways. Golden, CO: National Renewable Energy Laboratory, NREL/CP-550-43238.

International Code Council, Inc. (2006). 2006 International Energy Conservation Code. ISBN-13: 978-1-58001-270-6.

Lee, E.; Selkowitz, S; Clear, R; DiBartolomeo, D; Klems, J; Fernandes, L; Ward, G; Inkarojrit, V.; Yazdanian, M. (2006). Advancement of Electrochromic Windows, Sacramento, CA: California Energy Commission, PIER, 500-01-023, LBNL-59821.

Sbar, N. (2009). Vice President Technology, Sage Electrochromics, Inc. Personal communication, October 23. 


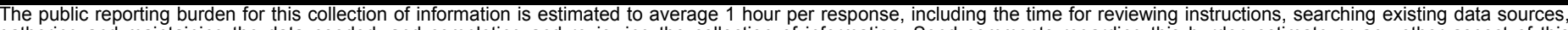

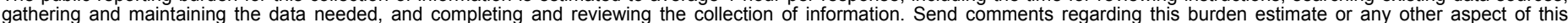

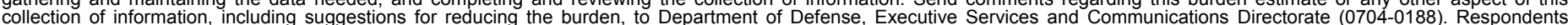

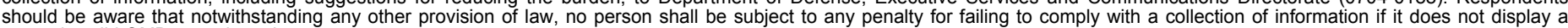

should be aware that notwithstanding

PLEASE DO NOT RETURN YOUR FORM TO THE ABOVE ORGANIZATION.

\begin{tabular}{l|l|l|l} 
1. REPORT DATE $(D D-M M-Y Y Y Y)$ & 2. REPORT TYPE & 3. DATES COVERED (FrOm - TO)
\end{tabular}

December 2009

Technical Report

4. TITLE AND SUBTITLE

Preliminary Assessment of the Energy-Saving Potential of

Electrochromic Windows in Residential Buildings 5a. CONTRACT NUMBER

DE-AC36-08-GO28308

5b. GRANT NUMBER

5c. PROGRAM ELEMENT NUMBER

5d. PROJECT NUMBER

NREL/TP-550-46916

5e. TASK NUMBER

BET98001

5f. WORK UNIT NUMBER
7. PERFORMING ORGANIZATION NAME(S) AND ADDRESS(ES)

National Renewable Energy Laboratory

1617 Cole Blvd.

Golden, CO 80401-3393
8. PERFORMING ORGANIZATION REPORT NUMBER

NREL/TP-550-46916

9. SPONSORING/MONITORING AGENCY NAME(S) AND ADDRESS(ES)

10. SPONSOR/MONITOR'S ACRONYM(S)

NREL

11. SPONSORING/MONITORING AGENCY REPORT NUMBER

12. DISTRIBUTION AVAILABILITY STATEMENT

National Technical Information Service

U.S. Department of Commerce

5285 Port Royal Road

Springfield, VA 22161

13. SUPPLEMENTARY NOTES

14. ABSTRACT (Maximum 200 Words)

Electrochromic (EC) windows provide variable tinting that can help control glare and solar heat gain. We used BEopt software to evaluate the performance of EC windows in prototypical energy models of a single-family home in Atlanta. The windows were assumed to operate automatically, tinting in response to incident solar during the cooling season. The models predict the EC windows will produce whole-house source energy savings of $18.2 \%$ and wholehouse electricity demand savings of $13.5 \%$ in a 2006 IECC-compliant home, and source energy savings of $8.2 \%$ and demand savings of $10.3 \%$ in a $50 \%$-level Building America home.

15. SUBJECT TERMS

electrochromic; ec; windows; tinting; glare; solar heat gain

\begin{tabular}{|c|c|c|}
\hline $\begin{array}{l}\text { a. REPORT } \\
\text { Unclassified }\end{array}$ & $\begin{array}{l}\text { b. ABSTRACT } \\
\text { Unclassified }\end{array}$ & $\begin{array}{l}\text { c. THIS PAGE } \\
\text { Unclassified }\end{array}$ \\
\hline
\end{tabular}

\begin{tabular}{l|l|}
$\begin{array}{l}\text { 17. LIMITATION } \\
\text { OF ABSTRACT }\end{array}$ & $\begin{array}{l}\text { 18. } \\
\text { NUMBER } \\
\text { OF PAGES }\end{array}$ \\
UL &
\end{tabular}

19a. NAME OF RESPONSIBLE PERSON

19b. TELEPHONE NUMBER (Include area code) 